\title{
Problems of using the energy service contract in Russia
}

\author{
Tatiana Meshcheryakova* \\ Moscow State University of Civil Engineering, Yaroslavskoe shosse, 26, Moscow, 129337, Russia
}

\begin{abstract}
Subject of study. One of the most popular investment mechanisms in the field of energy saving in Europe is the energy service contract. The importance and prospects of its application in Russia began to be perceived at the state level 9 years ago. Despite the active work of government agencies on the implementation of energy-saving measures, including the financial aspects accompanying them, the barriers to the implementation of the energy service contract are growing. Goals. It is required to identify the key barriers that hamper the development of the energy service contract and form possible recommendations that allow the situation in the energy services market to be determined in a conclusive manner. Materials and methods. The study uses official data from the reports of the Ministry of Energy, statistics of the Russian Association of Energy Service Companies (RAESCO), the latest amendments and additions to Federal Law No. 261 "On Energy Saving ... ". For the analysis, scientific methods such as logical and graphical methods, analysis and synthesis, a systematic approach, a logical method of knowledge of the subject domain are used. Results. Introduced at the federal level legislative changes in the field of energy inspection, completely abolishing the concept of "compulsory energy inspection" will negatively affect the market of energy services. In conditions that involve the survival of the strongest energy service companies, a new approach is proposed for the implementation of energy service contractsoutsourcing an energy service company. Conclusions. In the conditions of annual reduction of budgetary funds for energy-saving measures, the energy service contract is a indispensable and non-alternative investment mechanism that allows implementing state tasks in the field of energy saving and energy efficiency. It is necessary to provide state support and review of existing approaches to the application of the energy service contract.
\end{abstract}

\section{Introduction}

To date, energy conservation and energy efficiency are key factors in improving the efficiency of the economy as a whole, allowing to save money by using new or modernized equipment that reduces the consumption of fuel and energy resources, as well as being able to have a positive impact on the ecological situation, both in individual regions and at the level of the whole country. In this context, various mechanisms of energy conservation of

\footnotetext{
${ }^{*}$ Corresponding author: MeshcheryakovaTS@mgsu.ru
} 
technical and organizational order acquire special significance. One of these mechanisms is the energy service contract, which acts in the form of an investment contract entered into by the contracting authority with the executing organization (energy service company). Energy service contract is one of the most promising mechanisms for energy saving and energy efficiency. The key principle of the implementation of the energy service contract is that the Customer does not divert his own funds from the turnover for the implementation of an energy efficient project. This issue is especially relevant for budgetary institutions, in the budget of which very rarely are funds for the modernization of fixed assets.

\section{Literature review}

Recently, you can see a significant number of publications on research in professional and scientific journals due to the obvious problems in the market of energy services. Here is the most important information, based both on the data of the expert community.

According to information from the RAESCO reports on the market of energy services in 2016-2017. there is a huge growth in the market of energy services [1,2]. Despite the reduction in the number of contracts concluded, the total cost of the contracts increases, which characterizes the market orientation towards high-cost and highly profitable energyefficient projects (Fig. 1).
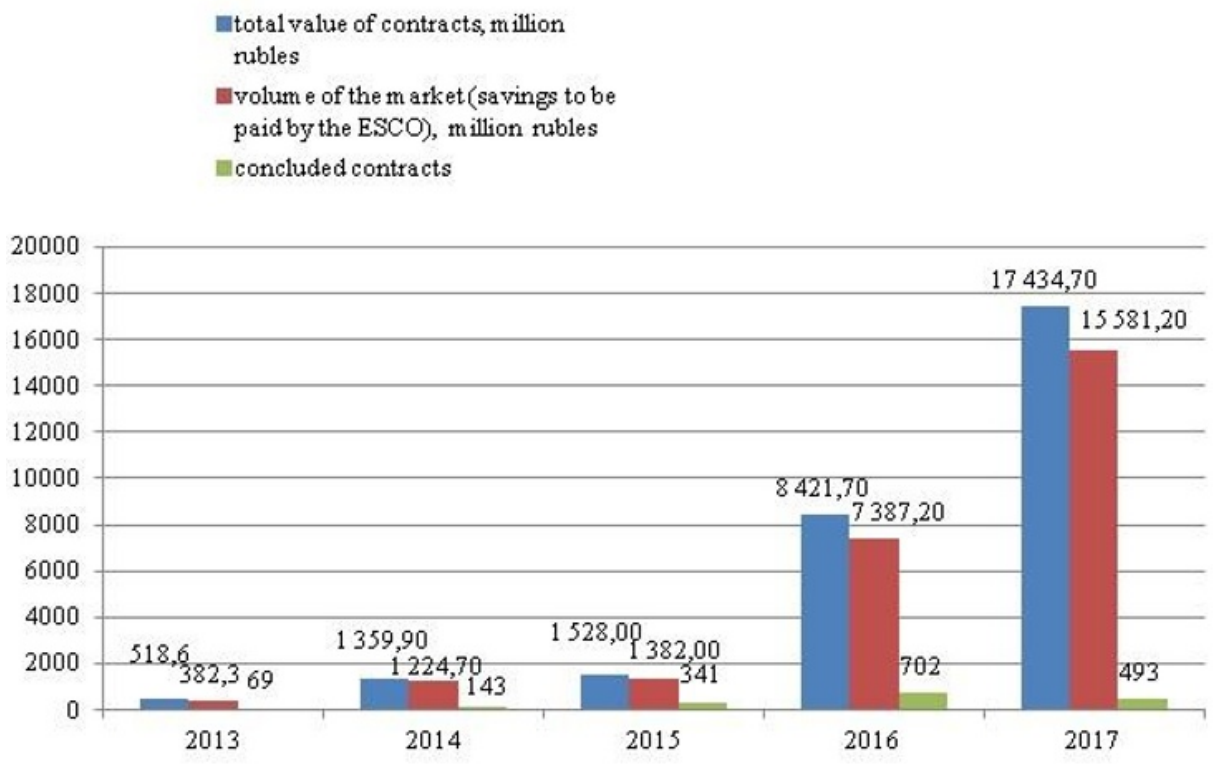

Fig. 1. Dynamics of the market of energy services

However, the achieved indicators during the current and next year will be difficult to maintain. The market for an energy service contract is not being distributed at the regional level, and current legislation does not contribute to solving existing problems.

\section{Materials and methods}

The analytical part of the study is based on information from the official data of the RAESCO and regulatory and legal documents regulating the activities of energy service companies. The main normative and legal document that determines the principles for the 
implementation of the energy service contract is the Federal Law No. 261-FZ "On Energy Saving ...". The tender basis for the participation of energy service companies in the implementation of energy-saving measures is presented in 44 and 223 Federal laws on procurement detail $[4,5]$.

The research uses various general scientific methods. Logical and graphical methods allowed conducting a retrospective analysis and revealing the current situation in the market of energy services. The method of synthesis and the system approach allowed to understand the existing contradictions in the law and to state the formulation of existing and prognostic problems. The logical method of cognition of the domain allowed assessing the possible prospects for the development of the market for energy services and identifying the most appropriate solutions to problems.

\section{Results}

The effectiveness of the application and use of energy service contracts is confirmed throughout the world. Russia was no exception. With the adoption of the Federal Law No. 261-FZ "On Energy Saving ..." mechanisms for implementing energy-saving measures have been given considerable attention in all spheres of economic activity. Particular activity of both the state structure and energy service companies in energy saving issues was demonstrated during the next several years on the wave of a general resource saving trend. Starting in 2013, democratization of energy saving procedures began, which consists in reducing mandatory energy saving procedures. It should be noted that, according to Art. 16 Ch. 4 No. 261-Ф3 obligatory energy inspections obliged to conduct a significant number of persons, including organizations whose total costs for the consumption of natural gas, diesel and other fuel, fuel oil, thermal energy, coal, electric energy exceed ten million rubles per calendar year. With the adoption of Federal Law No. 399 of December 28, 2013, "On Amending the Federal Law "On Energy Conservation ... ", individual entities withdrew from the list of persons subject to mandatory energy inspection.

The indisputable fact is that the mandatory energy inspection was the locomotive of the energy service for many years. According to the principles underlying the energy-efficient policy pursued by the Government, the examination of facilities, the definition of "problem zones" in the directive format, made it possible to identify a general view on energy costs, develop energy-efficient energy-saving measures, and start implementing them in an uncompromising manner $[6,7]$. The collected statistics also provided the formation of the base of the State Information System "Energy Efficiency". This made it possible to monitor the situation for the federal executive bodies, executive authorities of the subjects of the Russian Federation and local self-government bodies influenced the development of technology requirements systems and the development of industry directories of the best available technologies.

Current trends in energy saving and energy efficiency at the legislative level make it possible to draw the following conclusion: state policy implies inertial development of energy efficiency - by providing initial stringent conditions for many participants, both energy-intensive and relatively low-energy consumption, now includes self-discipline and personal interest in energy saving. Term comes into effect the Federal Law № 221-FZ of 19.07.2018 "On Amendments to the Federal Law" On energy saving ... "eliminates the category of" compulsory energy inspection. " This change cannot but affect the market of energy services, of course, there will remain motivated customers with significant reserves for 
energy saving and are motivated to implement projects using the energy service contract mechanism. Demand for energy service companies will be determined by a very narrow and motivated, and therefore, a qualified and relatively qualified group.

In the market of energy services there are other problems that need to be addressed.

First, the constraining factor in the development of the market for energy services is a rigid framework regulation by the state on the basis of Federal Law No. 44 "On the contract system" $[4,5]$. Cases that do not require a contract to be performed in accordance with clause 8 of Article 96 of Federal Law No. 44 should include energy service contracts, since, unlike traditional contractual agreements, all risks, as already said, are borne by the contractor. The principles, the determination of the winners of the competitions, presuppose the choice of the company offering the lowest price. This fact can only play a negative role, as it constrains the capabilities of an energy service company, which in this case should focus not on a high long-term effect, but on a low cost of work. In such conditions, companies that offer high-cost, and at the same time, high-yield services, do not have a chance to receive an order.

Secondly, from the position of the contractor - a professional company that implements the contract, one of the most important unsolved problems remains the system of attracting funds from financial institutions. The big risks of non-fulfillment of obligations by the energy service company to banks restrain their potential opportunities, determining the share of instability in the market of energy services. It is this issue that plays the most important role in the development of the energy service contract in Russia and forms the problem field for the key participant - the energy service company.

Third, from the position of the customer - industrialists or owners or the managing organization, there is still no understanding of the essence of the mechanism of the energy service contract, and for the vast majority of the population the term "energy service contract" is generally unfamiliar.

\section{Conclusions}

The implementation of large-scale projects with a high level of lot prices and, accordingly, a high level of savings is beyond the power of small businesses. At the same time, it is the small business that must provide the main market for energy services, since the "true" energy service, in which the mechanism for implementing energy-saving measures with an "extended" effect is laid down, to large players, cannot be interesting, especially given the current economic conditions management: taxes, salaries, interest on the loan. The monthly or quarterly profit received during the implementation of energy service contracts is postponed and stretched for years.

Without government support, energy service contracts are becoming less attractive with each passing month. One of the possible ways out of this situation is outsourcing an energy service company or hiring "energy service" specialists to the staff of the Customer's organization. Having behind him the experience of implementing energy-saving measures, experts will select the most appropriate activities and recommend them for execution. The argument in favor of such a proposal is that, in most cases, legal entities, with a serious consumption of fuel and energy resources, lack specialists who are able to professionally draw up a real energy saving program.

A great potential for energy saving and energy efficiency is found both in the most energy intensive sphere - industry, and in the budgetary sphere and housing stock, where the prospects for developing a contract for energy services are just beginning to be evaluated. It is necessary to ensure the beginning of active work at various levels of executive power, aimed at improving approaches to the implementation of the contract for energy services. 


\section{References}

1. Association of energy service companies - RAESKO. Overview of the Russian energy services market for 2016 (2017)

2. Association of energy service companies - RAESKO. Overview of the Russian energy services market for 2017 (2018)

3. On Energy Saving and on Improving Energy Efficiency and on Amending Certain Legislative Acts of the Russian Federation, Federal Law N 261 (2009)

4. On the contract system in the sphere of procurement of goods, works, services to ensure state and municipal needs, Federal Law N 44 (2013)

5. About purchases of goods, works, services by separate types of legal entities, Federal Law N 223 (2011)

6. An.B. Mottaeva, As.B. Mottaeva, Int. Journal of Applied Engineering Research 1, 11-9 (2016)

7. Stein, E., Taskaeva, N., Chibisova, E. Procedia Engineering 165, 1410-1416 (2016) 